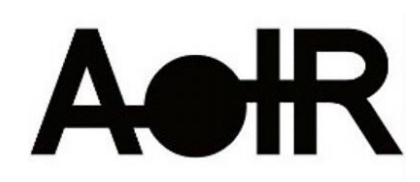

Selected Papers of \#AolR2021:

The 22nd Annual Conference of the

Association of Internet Researchers

Virtual Event / 13-16 Oct 2021

\title{
HASHTAG ACTIVISM LOST IN TRANSLATION: THE REFORMULATION OF \#METOO IN JAPAN
}

\author{
Mizoroki, Saki \\ The University of Tokyo, The Hebrew University of Jerusalem \\ Shifman, Limor \\ The Hebrew University of Jerusalem
}

Hayashi, Kaori

The University of Tokyo

In 2017, the \#MeToo movement lit up Twitter. In Japan, however, it was almost nonexistent and morphed into other forms of hashtag activism: \#WeToo, \#WithYou, and \#furawademo ("flower demo"). This paper investigates both the absence of \#MeToo in Japan and its reformulations. We hypothesize that these could be explained through the interplay of three avenues: (1) values-the literature on values in Japan foregrounds harmony, collectivism, and the avoidance of shame; (2) Topic_-gender and sexual harassment_-drawing on literature on the rootedness of sexism in this society; (3) Platform-mounting concerns over privacy issues on Twitter in Japan. We conducted fifteen interviews with Japanese men and women from varied backgrounds and assembled 119 newspaper articles that explain why people are reluctant to speak up. We applied a combination of grounded and thematic analysis to analyze these samples. Our analysis affirmed that the three avenues are key to understanding the movement's absence and reformulation. Perceived Japanese values clash against the values that respondents and newspapers detected in the movement, and the new formulations are evaluated as "softening" the protest by blending in acceptable values. However, while most participants appreciated the movement, they were afraid of retaliation and isolation, given their perception of Japanese values. We tentatively argue that it's not values as essential orientations but the prevalent perceptions of popular values that limit activism. Such perceptions of national values become self-fulfilling prophecies; people "perform" the values that they think others will appreciate and, in so doing, reinforce those values.

Suggested Citation (APA): Mizoroki, S., Limor, S., Hayashi, K. (2021, October). Hashtag Activism Lost in Translation: The Reformulation of \#metoo In Japan. Paper presented at AolR 2021: The 22nd Annual Conference of the Association of Internet Researchers. Virtual Event: AolR. Retrieved from http://spir.aoir.org. 